手技・工夫と成績

大阪市立大学第 2 外科

李栄柱，大杉治司，竹村雅至，西川隆之，福原研一朗， 岩崎洋

【目的】当科での進行胸部食道癌に対する胸腔鏡下手術 の手技・工夫と成績を供覧する.【対象・術式】cT $1 \mathrm{~b} \sim \mathrm{T}$ 3 , 右肺虚脱下麻酔維持可能, 広範囲胸膜撚着がない胸 部食道癌に対して，1996年より2004年4月までに小開胸 併用胸腔鏡下手術を施行した132例（うち pT 3：40例) および通常開胸 pT 3 症例48例を対象とした。術式；第 5 肋間中腋䆚線上に $5 \mathrm{~cm}$ の小開胸とこれを囲むよう に 4 個のポートを挿入、小開胸創より気管圧排鈎を挿入 し䋛隔展開し視野を確保する。胸腔内操作は基本的に開 胸と同等である.【成績】 pT 3 胸腔鏡下手術症例の胸部 手術時間は208分，出血量は251 g, 胸部操作郭清リンパ 節個数は36個， 2 年生存率は $78 \%$ であった. 通常開胸 $\mathrm{pT}$ 3 症例の胸部手術時間は 202 分, 出血量は299 g, 胸部操 作郭清リンパ節個数は36個，2 年生存率は56\%であった。 2年生存率において，胸腔鏡下手術症例群が高いが有意 な差は認められなかった。【結語】pT3 進行胸部食道癌 においても，小開胸併用胸腔鏡下手術により通常開胸と 同等の手術が可能である。

\section{VS-6-5 進行食道癌に対する胸腔鏡下リンパ節郭} 清術

大阪市立総合医療センター消化器外科

東野正幸, 谷村愄哉, 福長洋介, 岸田哲, 尾方章人, 藤原有史

胸腔鏡下食道切除を遒入して9年が経過するが当初よ り進行食道癌も対象としてきた。これまでに227例の胸部 食道癌に胸腔鏡下食道切除を行ってきたがその梁達度を 見ると $74 \%$ は 2 以深の症例が占めていた。食道癌手街 では手術範囲が頸胸境界部から横隔膜上まで，また右側 から左側縦隔樑部まで及ふ。鏡視下手術では通常開胸に 比へて狭いワーキングスペースでも十分拡大視された視 野で操作が可能でこの利点をいかしたリンパ節郭清が可 能である. 現在では左右気管支動眽の末梢まで確認し, 温存することに努めている。大動脈弓下でも左迷走神経 から左反回神経が分岐する部まで神経，動脈を温存して の郭清を行っている，食道の剢離層を対側縦隔胸膜, 大 動脈, 心膜を露出する層とすることで開胸術において困 難であった下行大動脈左側, 左右肺門, 気管分岐部りン パ節の en-bloc 郭清が可能となった. 鏡視下手術は通常 開胸に比べて拡大視可能のため狭いワーキングスペース で良好な視野での操作が可能となり，胸部食道癌根治 手術に適した手術であると考えている。これらの手技を ビデオで供覽する。
除術

東京都立墨東病院外科

梅北信孝, 真栄城剛，三島秀樹，鶴原知子，志波佳代子， 田中壮一, 宮本幸雄, 井上晓, 吉田操, 北村正次

目的）我々は原則として進行食道癌に对しても開胸，開 腹を伴わない完全胸腔鏡, 腹腔鏡下の食道切除再建術を 施行し報告してきた。今回は進行癌に対する上緥嗝郭清 の手技を中心に報告する，対象および方法）2001年10月 から胸部食道癌32例に施行した，最近の進行症例では術 前放射線化学療法を施行し downstageしている.腹部操 作は全例腹腔鏡下に胃管を作成したが，胸部操作は高度 胸膜瘾着例と T 4 症例に小開胸を追加し用手補助とし ている．腹腔鏡操作を先行し胃管を作製，胸腔鏡淥作後 胃管と病変を含む食道を後緹隔経路で頝部に抜去し吻合 する，腹腔鏡操作により下縦隔郭清を中部食道まで行う が，拡大視効果により容易である．腹腔鏡下に下綐隔郭 清を行って括けば胸腔内操作は中部食道より頭側のみで よく術者, 助手とも同一視野で行うことができるため hand-eye-co-ordination が容易である。反回神経周囲 の郭清は，気管を Endo-retracter て圧排し，超音波凝固 装置および bipolar scissorsを用いて行い頸部まで㓦離

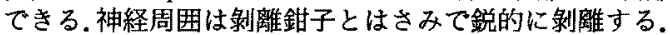
結語）内視鏡下手術は通常開胸と同等の根治性を得るこ とが可能である。

VS-6-7 Hand assisted laparoscopic \& thoracoscopic surgery (HALTS) と鎖骨挙上法に上る食道 癌 3 領域郭清術の低侵襲化

東京慈惠会医科大学外科学講座

鉿木裕, 羽生信義, 中田浩二, 石橋由朗, 小村伸朗, 川渏成郎，矢永勝彦

Hand assisted laparoscopic\& thoracoscopic surgery (HALTS)による食道癌 3 領域郭清術の手技と成績を報 告する。(手術手技)体位は仰臥位，麻酔仙両側換気，頚 部・小览用ケントで鎖骨を童引举上し，両側䅡部扔よび 上綐隔を郭清，頝部と同時に上腹部正中切開 $($ 約 $7 \mathrm{~cm})$ で開腹し 3 ポートから腹腔鏡下に胃周囲リンパ節と下縦 隔リンパ節を郭清。次に左側卧位，左片肺換気。胸部に 4 本のポートを挿入し腹部創より胸骨後経路で右胸空内 に左手を插入，中綖隔を郭清，再度両側換気仰卧位に戻 L，後綐隔経路で胃管を挙上させ頝部食道と吻合（対象 と結果）2002年 9 月から2004年 4 月間に当院で低侵襲食 道癌手術を施行した18例 (年歯令 : 44-71 平均60.8歳,男) 女 $=14 / 4)$. 術後在院日数11.3日，リンパ節郭清個数39 個, 術後合併症(肺炎 $5.6 \%$ ，縫合不全 $5.6 \%$ )，職場復帰 率 $100 \%$ ，入院医療費202.5万円. (結論) われわれが考 案した HALTSによる 3 領域食道癌手術は, 根治性を損 なうことなく，低侵襲，安全かつ経済的である。 
VS-6-8 進行食道癌に対する induction chemoradiation therapy+胸腔鏡下切除術

福岡大学第一外科")，大分大学第二外科 ${ }^{21}$

山本婹 ${ }^{11}$, 白石武史 ${ }^{1)}$, 前川(隆文 ${ }^{1}$ ， 川原克信 ${ }^{21}$, 白日高歩"

〈対象>2004年 4 月までに食道癌に対する胸腔鏡下手術 は105例で, 病期分類は Stage 0 3例 $(2.9 \%)$, Stage I 23 例 $(22.5 \%)$, Stage IIA 21例 (20.6\%), Stage IIB 15例 $(14.7 \%)$, Stage III 16例 $(15.7 \%)$, Stage IV 24例 (23.5\%) であった。記注例のうち術前放射線化 学潦法を施行した24例を検討した, regimen は40Gy + low dose CDDP+5-FUを12例に, 7 例に30Gy + low dose CDDP+ $5-\mathrm{FU}, 3$ 例に $40 \mathrm{~Gy}$ の radiation, 各々 1 例に60Gy + low dose CDDP + 5-FU, 40Gy + low dose CDDP+ 5-FU+ paclitaxel を施行. <結果 $>$ 食道 癌に対する街前放射線化学療法に拈ける重第な合併症は みられなかった。効果判定は PR17例, NC 7 例であった。 胸腔内手術時間 $111 \pm 29 \mathrm{~m}$, 胸腔内出血量は平均 $121 \pm 105$ $\mathrm{ml}$, 綖隔りン節郭清数は平均 $30 \pm 9$ 個で, 術前放射線 化学療法を施行しなかつた群と比較しても琴はみられ ず，放射線化学療法による胸腔鏡手術への影響はなかっ た. 予後は NC 症例に 1 年以上の生存例はなかったが, PR17例の 5 年生存率は $63.5 \%$ と良好で, NC 群 7 例と比 較して有意に予後の改善がみとめられた。結論〉進行 食道癌症例においては, 術前放射線化学療法は胸腔鏡下 切除および䋛䧣りシパ節郭清を困難にするものではな 〈, PR 以上の response 方得られる症例において予後の 改善が十分期待できる。以上の成續とともに，実際の手 技をビテオで供覧し，胸䐩鏡手技ののポイントを解説す る.

\section{VS-7-1 呼吸器外科手術の最近の動向}

石川県立中央病院呼吸器外科 ${ }^{11}$, 金沢大学心肺 - 総合外 科 ${ }^{2)}$

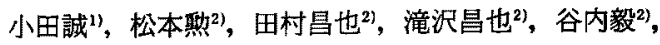
户田有宣 ${ }^{2)}$, 川上和之文，谋邊剛|2)

【背景・目的】呼吸器外科手術は拡大手街と縮小手術の 両方向へ分化している，縮小手術では，胸腔鏡の学入に よる創の縮小，肺癌手術における切除肺容量の縮小ょよ びリンパ節郭清の省略が話題である。縮小手術，抬大手 術ともに安全に施行できることが必要条件である.【胸腔 鏡手征】創縫合を必要としない $2 \mathrm{~mm}$ ポートからの needle scopic 手術を胸部交感神経節遮断術, Nuss 法の補 助, 䋛隔腫瘍, 胸膜生検, 肺生険に施行しおり, 疼痛は 著しく軽減されている、【肺癌手術】cIA 期肺癌に対して は胸腔鏡手術をそれ以外の病期に対しては，12cm 開胸 での手術を原则としている.胸腔鏡手術でのリンパ節郭 清には 3 D 内視鏡システムを使用しているが，立体画像 が鮮明に得られ有用と考えている.cIA 期肺癌において， S 6 , 左上葉原発例に対して注積極的に区域切除術を, 右 上葉, 左上区原発例には形闪下のリンパ節的清を省略し ている.【拡大手術】特に進行肺湢に対して，上大静脈合 併切除，大動脈合併切除，椎体合併切除等を施行すると 共に，体外肺切除術を検討している。【まとめ】 Needle scopic 手術, 3 D 内視鏡システム, 肺癌に对する各手術 手技を中心に解説，供覽する。
VS-6-9 食道癌に対する鏡視下手術をストレスな く尊入するための工夫

都立駒込病院外科"，都立墨東病院 ${ }^{21}$

出江洋介"1), 太田正穂"), 川田研郎"), 吉田操2)

2000年から2003年までの食道切除術189例中15例に鏡視 下手術を導入し，検討した。侵䘫や食事摄取に関連する QOL は open 手術と鏡視下手術で大きな差異はない. 鏡 視下手街が開胸手術より明らかに優れている点は，拡大 視効果により狭いスペースでの精細な手術操作が可能な 点である。また呼吸機能の回復が良好で, 少開胸 $(6 \mathrm{~cm})$ を併用しても長期的な創の遧和感は少ない。一方視野の 展開は, open 手術の方が容易である.胸腔鏡下手術でス トレスを生む原因は，鉜子の自由度が制限されることと と触覚がないことによる安全確認が行いにくいことであ る. 以上の検討から，open 手術の良い点を残しつつ，胸 腔鏡の利点を最大限に発揮する方法として, 前方の少開 胸創 $(6 \mathrm{~cm})$ から肋骨を切離し後方へ助間筋のみを切離 した状態で，胸腔鏡下手術を行う術式を考案した。手が 自由に㨀入可能になり，鉗子操作の自由度が増した。本 術式の利点は（1）肋間の制限が少なく，鎮子を抵抗な く動かすことが可能，(2)触覚を利用した剥離操作が可 能，(3)肺の展開が容易なことてある. 手術の流れも通 常のOpen 手術と同様であり，違和感なく暗入可能であ る.本術式は，open 手術の利点を残しつつ鏡視下手術の 䯭れた点を比較的小さなストレスで導入する方法として 有用な術式と考えられたため報告する。

\author{
VS-7-2 前維隔疾患に対する胸腔鏡下手術と開胸 \\ 手術の適応評洒 \\ 東北大学呼吸器外科 \\ 松村輔二, 田畑俊治, 岡田克典, 星川康, 桜田晃, \\ 佐渡哲，鉿木聡，近藤丘
}

従来，前縦隔疾患の手術は胸骨正中切開で行われてきた が，近年，鏡視下手術も選択肢となりつつある。当科で は，これまで重症筋無力症( $\mathrm{MG}$ )20例(胸腺腫合併 6 例)， 成熟型奇形腫 3 例, 胸腺腫 4 例, 胸腺謇胞 1 例, 計28例 に鏡視下手術を施行した。同時期の開胸手術は36例 [胸 腺腫10例，リンパ腫 6 例，胸㙞癌 6 例，MG 5 例（胸腺 腫合併 4 例)，肧細胞悪性腫湯 2 例，甲状腺腫 2 例，胸腺 過形成 2 例，その他 3 例]で鏡視下手術は44\%であった。 鏡視下手尃適応は周团臟器・大血管と㭸着のない胸腺良 性腫煌, 周囲臟器浸潤のない胸腺腫 (径 $5 \mathrm{~cm}$ ) )で, 良 性疾患は片側胸腔アプローチを，MGの拡大胸腺摘除術 は両側肋間・胸骨下アプローチを基本としている。代表 例として胸腺腫合併 $\mathrm{MG}$ 症例で鏡視下手術の選択につ いて供覽する。【症例 1】34歳, 女性. MGFA 1 期, 胸 腺腫合併. 胸腔鏡下拡大胸腺摘除術施行.【症例 2 】57歳, 男性. MGFA 2 A 期, 胸腺腫合併. 胸骨正中切開拡大胸 腺摘除十右肺中葉部分切除十心膜切除術施行.【考察】鏡 視下切除を考慮する際は，周囲臓器への浸潤・癒着評価 が重要である.CT画像の評価には限界があり，鏡視下手 術開始早期に観察して評価することが大切である. 
Vs-7-3

普遍化を目指した完全鏡視下肺葉切除術

(VATS lobectomy) の工夫と成績

広島市立安佐市民病院外科

山下芳典，向田秀則，多幾山涉，嶋田徳光，坂部龍太郎， 山本英喜, 住谷大輔, 佐藤幸雄, 佐伯修二, 久松和史, 平林直樹

【目的】原発性肺癌に対する VATS lobectomy が, 開胸 下と同様な操作性がえられるよう手技や器具の工夫をし たのて，右上葉切除術と縦隔りンパ節郭清 (右上維隔と 左気管分岐部）をビデオで供覧する。【方法】31例の胸腔 補助下手術の後, cStage IA の非小細胞肺癌に対して16 例の完全鏡視下肺葉切除術を施行した。術者の視線方向 からの視野を確保するため, また容易に視野の変更可能 な軟性鏡を用いた。 $4 \mathrm{~cm}$ のウィンドウと 3 つのポート孔 を設け, 開胸器は使用しなかった。術者は原則として患 者の左側に立ち，ウィンドウは術者の右手用で，バイポ ーラシザーズの使用, 出血時の圧迫招よび切除肺摘出の 際に有用で，左手には胸空鏡用のドベーキーの鑷子を用 いた。肺門部の血管は被膜下処理とし, 系つきペンロー スを血管の裹面を通して自動縫合器で安全に切離した。 右上維隔のリンパ節郭清の際には縦隔胸膜を，気管分岐 部の部清ては左下葉気管支ごとエンドクロースで聯引し た.【成績】右上絴隔リンパ節の平均郭清個数は14個, No. 7 リンパ節は 3 個であった。平均手術時間 244 分, 出血量 $171 \mathrm{ml}$, 在院日数 9 日であり,術後の創部痛は明らかに軽 隇した、【結諭】術者のストレスは減じ操作性は向上し安 全に施行できた。

VS-7-4 胸腺腫に対する胸腔鏡下拡大胸腺摘出術 独立行政法人国立病院機構九州医療センター呼吸器セン タ一外科

竹尾貞徳, 福山誠一, 園部聡, 大津捸裕

【目的】当院独自の吊り上げ法を用いた胸腔鏡下拡大胸 腺摘出術をビデオにて供覧する。.【対象】1998年11月より 2004年 4 月まで13例で，47〜79才（平均62.7才）女：8 例, 男：5例である. 最終診断は, 正岡 I 期：8例(MG 合併 1 例), II 期：4例 (MG 合併 1 例), III 期：1 例 であった。【手術法】頸部の襟状切開及び季肋部の横切開 にて胸骨を吊り上げ, $5 \mathrm{~mm}$ の胸腔鏡を用い搪大胸腺 摘出術を施行，全例一塊にして腹部切開創より摘出した. 【結果】全例開胸への移行例はない. 腫题径は, 1.5 9. $0 \mathrm{~cm}$ (平均 $5.3 \mathrm{~cm}$ ), 出血量 $10 \sim 200 \mathrm{cc}$ (平均 $70.2 \mathrm{cc}$ ), 手 術時間180 345分 (平均294分) で合併切除は 1 例に肺, 心膜がある。術後合併症は, 横隔神経麻盘を 2 例に認め たが 1 週間以内に回復した. 術後退院は，7〜22日 (平 均10.5日）で最近は7日となっている. 観察期間 2〜66 ヶ月（平均36ヶ月）で，局所再発，遠隔転移共にない。 【結論】本術式の利点は安全で出血量が少ない。小さな 稘ですむ為, 術後疼痛が少ない, 久点は, 手術時間が長 いが, 最近は，3〜4時間になってきた。適応は, 腫瘍 の大きさに関係なく正岡分類の 3 期の肺，心膜浸潤まで としている.
VS-7-5 悪性胸膜中皮腫に対する胸膜肺全摘術 東京医科大学外科学第一講座

林和, 坪井正博, 臼田実男, 前原幸夫, 小鹿雅和,

吉田浩一, 暒原直央, 池田徳彦, 平野隆, 加藤治文

【背景と目的】覀性胸膜中皮腫は，定まった治療戦略が なくその中央生存期間は16か月と報告されている。一方 て肺癌に比して局所制御が生命予後に関与する重要な因 子であり，外科治療は集学的治療の key modalityであ る. 悪性胸膜中皮腫に対するいわゆる S 字切開により胸 膜肺全摘術を行なった 1 例を供筧する。【症例】59歳・男 性. IMIG 分類: IB 期( $\mathrm{T} I \mathrm{bN} 0 \mathrm{M} 0$ ) 0)悪性胸膜中 皮腫と診断し，化学療法を2コース施行した後に手術を 施行した。【手術手技】組織診未施行例であったため，ま ず第 6 肋骨床の壁側胸膜を切除し徒中迅速病理診断で胸 膜中皮腫を確認した。後側方切開を行い第 5 肋骨床より 壁側胸膜の剝離を肺尖から下方へ可及的に行なった。皮 虔切開線を前方から季肋下に延長して肋軟骨を前方て切 離して，横隔膜面および左 cost-phrenic angle の視野を 展開し全胸腔面の胸膜を剝離した，肺動静脈は心襄内て 処理し，左主気管支を離断して壁側胸膜，左肺，横隔膜 と心膜の二部を en blockに摘出した。術後経過は良好 て, 第21病日に退院. 術後病理組織䛦断は悪性胸膜中皮 腫であった.【まとめ】いわゆるS字切開により横隔膜面 および背側の cost-phrenic angle の良好な視野の確保 ができ完全切除をなしえた。

VS-7-6 Nuss 法16例の経験
松山心葴血管病院胸部外科
笠置康, 笠置真知子

【目的】Nuss 法を16例に施行したので報告する、【方法】 第一期手術時の年歯は 3 歳 12歳, 平均7.3歳. 男女比は 15：1であった。最陷凹部に一致した左右の第 8 肋骨の 走行に平行に約 $2 \mathrm{~cm} の$ 皮切を行い, 第 5 肋間より胸腔 内に入り用指的に前縦隔を剝離して Nuss の原法によっ て行った. Tevdek 3 禾 2 本を用いて Pectus barを 2 本 の肋骨に結禁固定した.胸腔内及び筇層下を兼奴た $1 / 8$ inch.径ドレーンチューブを左右に 1 本づつ留圆した.第 二期手術 (Pectus bar 技去術) 忧術後約 2 年で 9 例に施 行している.9例中１例は陥凹が残ったので再び Pectus bar を挿入した。【成續】Pectus bar の形成は中心部は比 較的直線上とし，左右の挿入肋間の部分より胸郭の形態 に合わせる様に形成した，前縦隔は用指的に娳離する事 により胸腔鏡を用いずよりスピーディーな手術を行い得 た. Pectus bar の形態, 胸腔扦入の部位及び Pectus bar の括入部位を最陥凹部より若干下の部分を挙上する事等 により, Pectus bar の固定は 2 本の肋骨に結梨するのみ て充分であった. Pectus bar を抜去する際, Pectus bar の癒着を剝離する為に Pectus bar を回転する事により 撚着煣離を行い得た. 1/8 inch.径ドレーンチューブを Pectus bar のカプセル内に留置した。【結論】(1) Nuss 法により良好な結果が得られた。 (2) 本術式を実施する にはコツを要する。（3）簡単な術式と思わず合件症を来 さない様詳細な注意が必要である。 
VS-7-7

大動脈疾患に対する緊急ステントグラフ

卜留膡術

金沢大学心肺 - 総合外科 ${ }^{1)}$, 金沢大学放射線科 ${ }^{21}$

大竹裕志")，木村圭一"1)，小杉郁子'，渡邊剛[1]，

真田䐓一郎 ${ }^{23}$ ，松井修 ${ }^{2}$

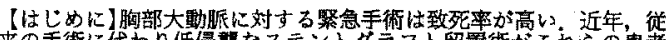

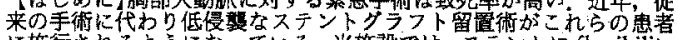
に施行されるようになっている, 当施設ては, ステントにflexibility

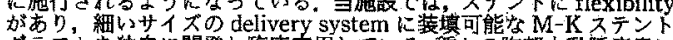

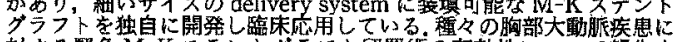

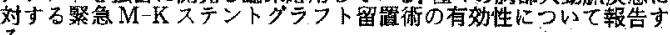
当.

【対象及び方法】2001年4月より， straightもし〈は curved M-K Z

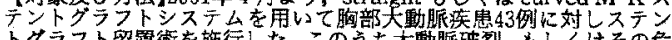
トタラフト留置使を施行した。

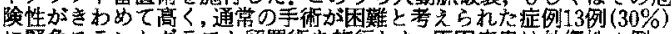

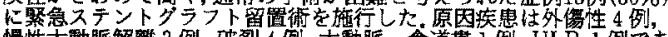

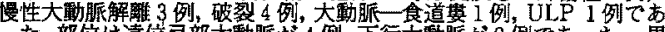
った：部位は遠倍部大動脈が 4 例，下行大動脈が 9 例てあった。男

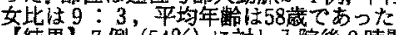

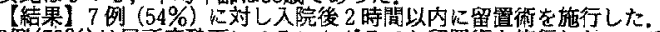

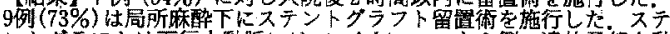
シトグラフトは下行大動脈比は straight type 9 例, 遠位弓部大動 脈活 curved type 4 例 (直径 $32 \mathrm{~mm}$ 加 $542 \mathrm{~mm}$ ) 老用いた。 シ

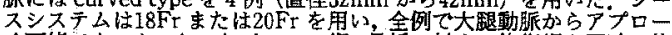

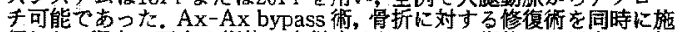

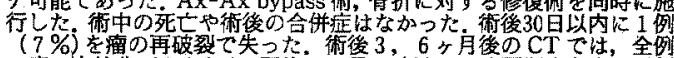

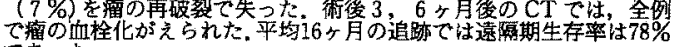
てあった。

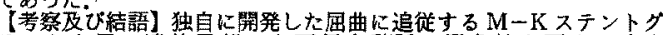

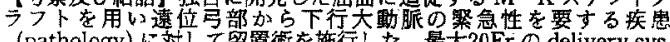

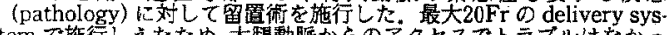

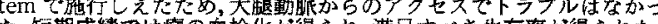

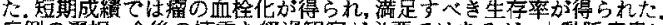
症例の選択，今後の慎重な経過䘽察が必要で汕あるが，大動脈疾惠に

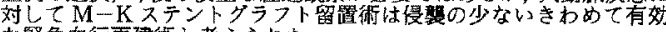
な祭急血行再建街と考えられた。

VS-7-8 低侵襲冠動脈完全血行再建術 一完全覚 醒下Cath-Lab Hybrid Procedure (カテ室での PCI, OPCAB 同時施行) -

西東京中央総合病院 ${ }^{11}$, 東京医科大学第 2 外科 ${ }^{2}$, 金沢大学 心肺・総合外科 ${ }^{3}$

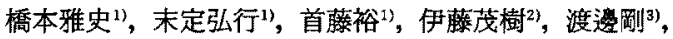
石丸新 ${ }^{2)}$

【はじめに】近年冠動脈バイパス街は off pumpをはじめと し低信翼化が頭著であるが, 経皮的冠動脈形成術 (PCI) の ほうが低侵襲でる。このPCI の利点を生かし，PCI 可能 部位にPCIを, PCI 困難部位のみへ低侵㜔化 CABG 方 室で同時施行することが，低僈警完全血行再建術式と考

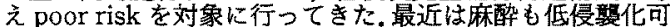
能と考え，気管内括管無しに硬膜外麻酔で完全覚醒自登呼 吸下にCABGを行うにいたつた。この症例を供覧卞る。 [症例] 80 歳男性. LAD seg $7 k 90 \%$ diffuse long, seg 13 K type A 099\%を有していた LAD に対し bypass, $\mathrm{Cx}$

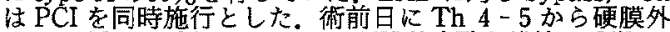
tube を括入. $2 \%$ アペインて硬膜外麻醉を維持. 手術は, Limb cage technique で胸骨を部分切開. LITA を採取。 off pump にて LITA-LAD吻合し閉創. つづいて PCI を施 行. この間, $\mathrm{O} 2$ マスクと硬膜外麻䡃のみで管理し, 麻酔科 Dr. と話しながら手術が進行した, PCI 終了後, 車いすにて 手術室を退室。術当日の夕食より常食の摄取が可能であっ

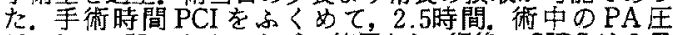
$18 \sim 25 \mathrm{mmHg}$, ネオシネジン使用なし, 術後のSIRS は2 2

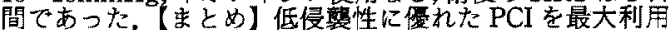

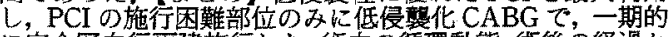

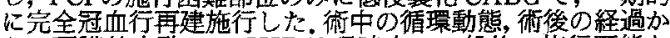
$\zeta$ ，硬膜外麻酔での CHP 法待点で一般的に施行可能な もっとも低侵警冠動脈再建術と考えている.
VS-8-1

連続 Gambee 法による消化管吻合どそ

のコツ

\section{八千代病院外科}

服部弘太郎，森浦滋明，小林一郎，吉岡裕一郎， 大城泰平, 川原真理，松本隆利

当院では消化管吻合に両端針付 4-0モノフィラメント 吸収系を用いた連続 Gambee 法を考案し1997年 7月よ り2004年 3 月まで食道, 直腸での機械吻合と穿孔性腹膜 炎のため吻合しなかった 4 例を除き緊急手術を合めたす へてての吻合に対して行っている，延べ420吻合の約 $3 / 4$ 海卒後 $2 \sim 5$ 年の医師が行った。消化管吻合を吻合の部 位別にA「置を含む吻合」B「小腸吻合」C「結腸を含を 吻合」に分類すると吻合による合併症のうち縫合不全は Bで 3 例，Cで1例みられたのみでAでの発生はなかっ た。吻合部狭窄が A で1例みられた，吻合合併症による 死亡は経験しなかった，縫合不全は絞拒性イレウスで温 存した小腸の断端壇死が 1 例，腹水をともなう腹膜播腫 による腸閉塞が 2 例，肝䇾曲部結腸疸で肝転移と原発巣 が一塊であったため一期的に拡大肝右葉切除と結腸右半 切除を行った腸䦥塞症例といった消化管の状態や適心に 問題がある症例に限られ満足できる成續であった。連続 Gambee 法は手技的にも比較的容易て材料費が節約て き医教経済的にも優れた方法といえる。また吻合に費や す時間も比較的短い. 連続 Gambee 法の手技を供覽し 吻合のコツを竍告するとともに消化管吻合について考察 した.

VS-8-2 胃・食道手術における linear stapler を 用いた機会吻合法

藤田保健衛生大学消化器外科

小森義之, 稲葉一樹, 殿村周平, 増井利㢁, 吉田郁男, 江原一尚, 庄司光孝, 中村康子, 宇山一朗, 桜井洋一, 落合正宏

食道切除後よよび胃全摘後の食道・消化管吻合は circular staplerによる吻合が行われる事が多いしかし， circular stapler による吻合は操作が困難な場合も多々, 操作中の食道損䂓および街後の吻合部狭㲛などの間題点 もある。教室で㤬食道癌手術における(胸腔内) 食道。 胃管吻合括よび胃全摘後の食道・空腸吻合に linear stapler (LS) を用いた勄合を施行し底好な結果を得ている ので，その手技の要点とこつをビデオで報告する、【食道 癌手術】吻合には镜視下手術用に開発されたLSを使用 し,食道断端々胃管断端を側々吻合する方法(機能的端々 吻合法)と食道と胃管を overlapさせて食道後壁と贯管 前壁を吻合する方法 (Overlap 法) 02 万の方法を施行し ている。禹者の吻合ともに食道切離端および管の口側 端あるいは胃管の前壁に小孔を作成し，LSのブレード をそれぞれの小孔活入し打針すことにより食道後壁と

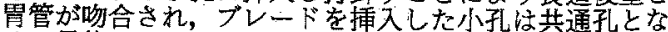
る.最後に staple line がV字に開くような方向に共通 孔を縫合あるいはLSを用いて閉鎖する。【胃癌手術】亩 全摘後の Roux-en一Y 再建時においてもLSを用いた機 能的端端吻合を施行している，手技ちょび原理は食道・ 管吻合の機能的端端吻合と同様てあり, 食道と空膓の 腸間膜対側とを LSを用いて側側吻合する方法である。 また食道を切断する前に食道・空腸をLS 後に食道の切断および共通孔の閉鎖を施行する方法もあ る. 
VS-8-3

用全摘症例に対する SurgASSISTを用

いた空腸 pouch 間置による上部消化管再建術

東大阪市立総合病院外科

宮崎知，伊豆蔵正明，西崖準一，奥邦彦，岡義雄，

中野博史, 西田幸弘, 酒田和也

[目的】迅速で安全な手術を目的に新しい手術器县によ る器械吻合が工夫きれている.今回, SurgASSISTを用 いた空腸 pouch 間置による消化管再建術を施行した青 癌全摘症例を供覧する。【症例】73歳，男性。平成15年12 月17日，体中部小弯の 4 型胃癌の診断にて開腹手術を施 行した。【手術所見】D 2 郭清を伴った胃全摘(胆寞合併 切除) を施行. 食道招よび十二指腸断端にサーキュラース テープルアシビルヘッド $(\# 25 \mathrm{~mm})$ を聥入. traiz 鞄带よ り $20 \mathrm{~cm}$ 肛門側の空腸を $40 \mathrm{~cm}$ に渡り横行結腸下に挙上 し，ストレートリニアカッターDLS $(2.4 \mathrm{~mm})$ を 3 回用 いて約 $15 \mathrm{~cm}$ の近位側 pouch を作成し, pouch 下端より サーキューラーステープル DLU $(\# 25 \mathrm{~mm})$ を挿入し食道 と空腸 pouch と端側吻合した。空腸導管は $10 \mathrm{~cm}$ とし, 断 端よりアンビルを㨉入し，十二指腸と端側吻合し，空腸 脚および空腸 pouch $\sigma$ 開口部はライトアングルりさア カッ夕ー $(45 \mathrm{~mm})$ にて閉鎖し，空腸空腸を端々吻合し再 建終了. 手術所見: UML 小弯 type $510 \times 5 \mathrm{~cm} \mathrm{sT}$ $2 \mathrm{~N} 1 \mathrm{H} 0 \mathrm{P} 0 \mathrm{M} 0 \mathrm{D} 2 \mathrm{PM}-\mathrm{DM}-$ sStage 2 . 病理所見 : ptype 5 T 2 (SS) poor 2 INFr int ly 0 V $0 \mathrm{n} 1 \mathrm{PM}-\mathrm{DM}-\mathrm{CY} 0$ pStage 2. 術後 8 日自よ り経口開始し，21日目に退院した。考察】SurgASSIST は組織圧を自動的に関知し，安定したステータリングが 可能である。本症例のような贯全摘後の空腸 pouch の作 成や再建には複数の吻合・縫合が必要でる゙，SurgASSISTを用いることにより安定した吻合，維合が可能と なり有用と思われた。

VS-8-4 器㭜による Billroth-1 法再建と胃切除 術

JA 岐皁厚生連西美濃厚生病院外科

飯田辰美, 宮原利行, 梅田幸生, 水谷密威, 後藤全宏

【目的】切除・吻合を合理化し，術者による偏りのない 安全確実な吻合をめざした。【対象】1996年3月より経験 した幽門側胃切除術が適応となる胃癌117例, 胃粘膜下腫 瘍 1 例，胃潰瘍 7 例，十二指腸潰場 3 例の合計128例に対 し器械吻合による Billroth-1 法再建術を施行した。【方 法】十二指腸肛門側断端はまつり縫い器を用いて吻合器 アンビル (A) を装着する (吻合器 $\mathrm{A}$ の经初褀の30例で $28 \mathrm{~mm}$ ，それ以後は $31 \mathrm{~mm}$ を使用), 胃角前壁に切開を行 い, 吻合器の軸を挿入，センターロッド（S）を吻合部に 貫通させる. A と S を結合させ吻合が完成する.その後, 自動縫合器を用い幽門側胃切除を行った。【結果】A 装 着, 吻合, 胃切除・断端縫合を全て器械を使用すること により10分以内でこれらの手㑯を施行できた. 術後合併 症をみると, 器械吻合施行128例中縫合不全例はなかった が, 輸血を要する吻合部出血が 1 例 $(0.8 \%)$, 切除断端て の悪性細胞陽性例が 1 例 $(0.8 \%)$, 術後イレウスが 5 例 $(3.9 \%)$, 逆流性食道炎 1 例 $(0.8 \%)$ であった。器械吻合 に起因すると考えられた吻合部狭窄は 5 例(3.9\%)で認 められ，1例で外科的処置を要した。【結語】本術式は鎌 度に影響されない切除・再建術式で，高りスク症例にも 適する。吻合器 $31 \mathrm{~mm}$ 径を使用し, 胃切除断端の奨膜筋 層縫合を追加しないことにより吻合部通過障害は隇っ た。 $\tau$

東京慈恵会医科大学 ${ }^{11}$, 東京慈患会医科大学 ${ }^{21}$

河原秀次郎 ${ }^{11}$, 平井勝也 ${ }^{21}$, 渡辺一裕 ${ }^{12}$, 横山正人 ${ }^{12}$, 良元和久 ${ }^{13}$, 柏木秀幸 ${ }^{11}$, 山崎洋次 ${ }^{21}$, 矢永勝彦 ${ }^{21}$

【緒言】大腸部分切除術を行う場合, 再建法として最近 では自動縫合器を用いた機能的端々吻合衍を用いること が多く，とくに右半結腸切除術で佩用されている.しか

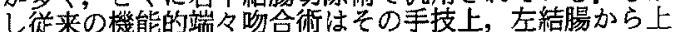
部直腸に用いられることはほとんどない，我々は，腸管 を交叉させて吻合することでどの部位の結腸でも自動縫 合器をもちいた器珹吻合を可能にしたのでその吻合法の 马ツについて報告する。【術式】自動縫合器を用いて腸管 を切断し標本を切除後, 口側およひ肚㑡腸管を $60 \mathrm{~mm}$ 程 交叉させた上で 3 力所支持系を扔き，腸管を固定する。 口側腸管の切断端より自動縫合器のカッ夕ー長 $(60 \mathrm{~mm}$ 程)の位置に小孔をあけて自動縫合器の片方のフォータ を挿入する，肛側腸管の切断端に小孔をあけ別の片方の フォークを挿入し側々吻合を行う.フォーク抙入口を数 針綘合閉銷後引L自動綘合器用的て綘合閉銷する。

以上により自動縫合器のカッター長の腸管の側々吻合 (吻合径約 $30 \mathrm{~mm}$ ) 加完成する.我々はこの吻合法を sliding functional end to end anastomosis (SFEEA) $\varepsilon$ 称 $L$ ている。【結果および考繁】術後注腸検査では吻合部が直 線化して扝り，従来の機能的端々吻合と比較してより生 理的と考えられたこれまで本法で右半結腸切除術32 例, 横行結晹部分切除術 4 例, 左半結腸術 2 例, S 状結腸 部分切除術14例，直腸前方切除術 6 例を施行したが，ど の部位の結腸でも容易かつ確実に吻合できた。

\author{
VS-8-6 翻転式 $\mathrm{J}$ 型結腸悬作成法 \\ 名古屋市立大学第一外科 \\ 竹山廣光，真辺忠夫
}

背景：下部直腸癌切除例にはJ 型結腸罴肍吻合術が機能 温存に優れていると報告されている．1986年にLazorthesらはJの頂点加ら線状縫合器の捙入する万法, Parc

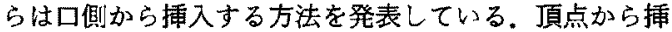
入すると捙入口が吻合口になるため，肚門吻合に不利で

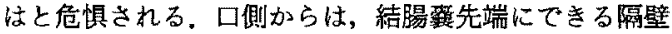
(apical septum) を処理し，㨉入口を閉鎖する必要があ る、いずれの久点も避けるため, 線状縫合器の挿入口を 必要としない方法を考案した．方法：折り返し部頂点に 当たる腸管全層を，肛門側断端から乗入したバブコック 鉗子で把持し，肛門側へ翻転する，腸間膜反対側を線状 縫合器で側側吻合する．翻転した腸管を元に戻し肛門側 断端を閉鎖すると J 型結腸呈は完成する，結果：動物実 験で問題ないことを確認後，臨床応用し有用であった。 考察：この方法の長所は, 器械挿入のための晹管切開が 必要でない点である。短所は，腸間膜の脂肪が多いと腸 管の翻転ができないことである。 


\section{VS-8-7}

新しい鏡視下手術を開く鍵一thumbs

up! knot

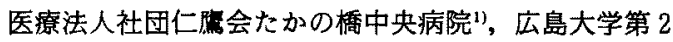
外科 ${ }^{2)}$

内田一徳"), 春田直樹 ${ }^{12}$, 岡島正純 ${ }^{2)}$

新しい鏡視下結㷊法 thumbs up! knot は，持針器で結栤 苇を巻き付ける従来の Square knot とは異なり, 持針器 のJawを開いたままで, 系を持針器自体に巻きとること によって結禁を完成する方法である。結禁のストレスは 主には，腹腔内を平面のモニターで見る空間認識，ト口 ッカーを支点とした銣子の可動域制限，鉗子同士の協調 運動による結禁系のコントロールの困難さから生じる。 我々の結禁法は，両手の協調運動を極力抑え，鉗子同士 を接触させることで遠近感の認識を容易にした。また， 持針器の Jaw 開いたまま結紮動作を行うことでルー プの slip out を防ぎ，確実で迅速な結愁を可能とした。 この方法は限られたスペース, Mirror image, 極端にト ロッカー間隔の狭い条件下でもスムーズな結热が可能 で，鏡視下体内結禁のストレスを軽減する新しい結禁法 である。
（はじめに）当科では金谷が考案したLinear stapler (LS)によるデルタ吻合を腹腔鏡下幽門側胃切除時の Billroth I 法再建に用いることによって完全に腹腔鏡下 で吻合操作を行っており,さらに食道切除再建術時の頸 部食道一消化管吻合に応用して（食道デルタ吻合）良好な 成績を得ているので報告する。(対象症例)腹腔鏡下幽門 側胃切除後再建 6 例に対しデル夕吻合を行い，胸部食道 切除後頸部食道一消化管の再建10例に対して食道デルタ 吻合を行った。(吻合方法)胃切除後再建では胃の大湾側 断端と十二指腸の背側断端に小孔を開け，それそれれの小 孔から LSを㧌入し，お互いの後壁を吻合した.この際, 頭側の胃,十二指腸の切離端を外側にに開いて切離端一汤 合ラインが約45度になるように注意した，食道再建の際 には，食道断端の一側と罢管または回腸の断端に小孔を 開けて，同様に後壁を吻合した。いずれの症例にお゙いて も，LSを㧌入した孔は再度 LSを 1 回ないしは 2 回用い て閉鎖した。（成績)腹腔鏡下幽門側胃切除時の再建，食 道切除再建術時の再建双方において, 術後, 吻合部の通 過は全例良好で，吻合に関する合併症は認められなかつ た。(結語) 上部消化管手術においてデルタ吻合, 食道デ ルタを応用した消化管吻合は，簡便で, 術後成績も良好 な安全確実な方法であると考えられた。
VS-8-9

腹腔鏡下胃切除術における安全，確実な

体内吻合法

大阪市立総合医療センター消化器外科

谷村慎哉, 東野正幸, 福長洋介, 山崎修, 西口幸雄, 松山光春, 堀井勝彦, 小川佳成, 清水貞利, 岸田哲, 玉森豊, 中澤一憲, 尾方章人, 藤原有史, 小川雅生

【目的】腹腔鏡下胃切除後の体内吻合を幽門側胃切(DG) に256例, 噴門側胃切(PG)に22例, 胃全摘(TG)に27例行 い, 安全て確実な体内吻合法について険討した。【万法】 DG256例中, HALS 例は106例, 全鏡視下例は150例て, そのうち169例に linear stapler を用いた三角縫合を行 った. PG では20例で circular stapler 考用いて食道残胃 または空腸吻合を行い，2例で linear stapler による食 道残胃また性食道間置空晹側々吻合を行った，TGでは 全例 circular stapler で再建を行ったが，1 例では経口 アンビル插入法による double stapling 法を施行した。

【成樍】DGにおける三角縫合では2例(HALS)に minor leakage を認めた. PG,TG での縫合不全は各 1 例(いずれも HALS)て，吻合時の状況から HALSまた は体外での吻合に切り替えた症例が各 1 例ずつみられ た.【結論】DG 後の三角綘合を用いた体内吻合柱安全な 再建法である，上部胃癌に対する鏡視下手術における再 建では, circular stapler 学用いた吻合が困難な症例で は, linear stapler を用いた側々吻合や経ロアンビル捙入 法を用いた double stapling 法も有用と思われた。

VS-8-10

腹腔鏡下直腸切除術における吻合法の実

際

群馬大学病態総合外科

浅尾高行, 山口悟, 坪井香保里, 井出宗則, 斎藤加奈, 深澤孝晴，堤荘一，桑野博行

鏡視下前方切除術においても局所再発の防止策として直 腸内洗浄や Dog Ear を残さない吻合法が求められてい る. 専用器具の開発を含めた工夫を紹介する.【方法・結 果】 1, Endo-Surg RetractorR(ESR)の開発 Port を占 有することなく wireで直腸の把持と内腔の閉塞ができ るESRを開発した。開腹術においても直腸䟝離操作の 補助具として, 直腸洗浄の際の内腔閉塞法として有用で あった。また ESRの把持により直腸を練くすることで 開口角に制限がある GIA を容易に装着することが可能 であった。 2, Dog Earを残さないDouble stapling technique 直腸を stapler にて切離後, dummy shaft

(DF) を装着した circular stapler を肛門より括入し $\mathrm{DF}$ を直腸閉鎖線の中央に貫通させる。直腸切離線に水 平マットレス縫合をかけ， shaft を越えて結禁すること で, 直腸切離断端が DFに巻き付くようになり,直腸閉鎖 線を circular stapler で打ち抜くことが可能であった。 【結語】器具と操作の工夫により亩腸に対する腹踛鏡下 手術がより簡便・安全に行える。 
VS-9-1 SM 罱㵝に対するD 2 郭清を伴う自律 神経温存幽門側䏴切除術

\section{広島市立広島市民病院外科}

二宮基樹，佐久木寛，矢野修也，久保陽司，佐藤太祐， 児島亭, 丁田录宏, 梅岡達生, 原野雅生, 青木秀樹, 小野田正, 塩崎滋弘, 大野聡, 桧垣健二, 高倉籍尚

【目的】SM 胃癌に対して根治性を保ちつつ術後消化吸 収機能と術後 QOL の改善をめざして自律神経温存幽門 側胃切除術を行っているので，この術式の㬰際を供覧す る.【術式の実際】No.4Sb 郭清における外側切離線を胃 大弯側と横行結腸との間に設定後に大網を胃大網動脈か 5 4-5 cm 離れた脂肪が踈な部で切離し, 横行結腸側 は温存する。迷走神経前幹から分岐する肝枝を温存した のちにNo.5郭清を行う. 引き続いて固有肝動脈の走行 を明らかにして，この前面を郭清後に固有肝動脈より内 側の組織を郭清する。この際に背面を走行する門脈を簬 出し、この腹側までを郭清する.総肝動脈周囲神経裳, 膵枝, 肝枝を温存する層で No.8a 前面の郭清を腹腔動 脈方向に進めていく，総肝動脈の頭側で背側よりを走行 する神経束を温存しつつ背側に郭清ラインを横隔膜脚ま で延長し No.90郭清と連ねる.No.11p の郭清を腹腔動 脈の方に進め，腹腔動脈左側で左胃動脈根部および腹腔 枝の走行を確認する。後胃枝を切離し腹㻮枝周囲の No. 7郭清を行う.左胃動脈は腹腔枝と分岥した末梢で切離す る.【結語ISM 胃癌において自律神経はD 2 郭清のよき 指標となりうる。

\section{VS-9-2 量癌手術における標準郭清 \\ 四国がんセンター外科 \\ 栗田啓, 久保義郎, 野崎功雄, 棚田稔, 高嶋成光}

胃癌に対するリンパ節郭清としてD 2 郭清を標準術式 としているが, 進行癌と早期癌ては㢦清度合いに自ずか ら違いがあってしかるべきと考える，治痹切除を目指し た進行癌手術に扔いては主要血管周囲の神経鞘を切除す るD 2 であり，自律神経も切雃，切除する。一方，早期 癌においては，血管鞘は温存し，迷走神経の腹腔枝をは じめとした主要自律神経の温存を図るべきと考えてい る.このコンセプトに基づき当施設で標準としているD 2 郭清を伴った胃切除術を供覽する。【早期癌】大網は温 存する。原則として胃癌がイドラインに沿った郭清を行 うが，D $1+\alpha$ の 7 番リンパ節に 8 番を加えている。 ンチネルリンパ節生検で経験, 過去のリンパ節転移の 頻度からも 8 番の郭清は必要と考えている. 迷走神経腹 空枝は温存するが, 前幹の肝枝の温存は必須とは考元て いない.【進行癌】T 2 , 前壁へのT 3 においては大網の 切除は行うが網賴切除は行っていない. 後壁へのT 3 に おいて網切除を行っている. 郭清は D 2 を原則とし， し領域のものにたいして肝十二指腸勒帯の郭清を追加し ている. 大動脈周曲リンパ節郭清は, JCOG9501の結果が 出るまでは原則行わないこととしている.
VS-9-3

胃癌に対するD 2リンパ節郭清の標準

手術手技

燕労以病院外科

藍澤喜久雄, 奥村直樹, 森岡伸浩, 清永英利, 宮下茬

【目的】胃癌に対寸るD 2 郭清は比較的安全に行われて いるが，さらに施設間差異を減らす目的て，D 2 郭清の 標準手術手技の設定が必要である. 今回，当科における 胃癌に対するD 2 郭清をビデオにて供覧し，安全で精度 の高いD 2 胃切除術について検討する。【手術方法】幽門 側胃切除の場合, 大網切除, no.4sb 郭清, および大弯側 の观理を行い, 次いで膵被膜制離からno.14v，6の郭清 へと連続させる.十二指腸切離後に no.50郭清を行い, 次いで no.12a，8 a の郭清を行う.No.11p 郭清では, 総肝動脈と脾動脈の分岐部,さらに脾動脈幹上縁で後腹 膜, 脾静脈が確害に露出されるように行う.No.11p 郭清 を後胃動静脈まで行い, no.9を郭清し, 左青動脈を結愁・ 切雐して no.7を郭清する。ささらに no.3，1 を郭清し, 迷 切を行い, 胃を切離する.上部進行胃癌に対する D 2 胃 全摘術では今のところ脾臓合併切除を行っているが, 左 側の大網切副線を後腹膜へと延ばし，脺脾を可及的に脱 転しておく.No.11郭清は, 脺体尾部, 脾を創外に挙上し て行い, 脺は温存する。最近では，脺脾温存胃全摘街の 可能性も検討されている。【結語】当科におけるD 2 胃切 除術は, 郭清の順序と範囲を明確にして行っており, 安 全で精度の高い標準手術手技と考えられる。

\section{VS-9-4 幽門側胃切除 D 2 郭清の手技}

札幌厚生病院外科

川村秀樹，近藤征文，岡田邦明，石津寬之，益子博幸， 田中浩一, 秦庸壮, 佐々木盛, 小原啓, 横田良一, 戸井博史，久慈麻里子，横田健太郎，中木村繁

D 2 郭清は D 1 郭清と異なり膵周囲を郭清することが 多く，梳液ろう発生を防止することがD 2 郭清のポイン トである. (手技)網篗切除，膵被膜の剶離は膵上緑まで 行っておくと郭清の層に容易に入ることができる，膵上， 緑のリンパ節郭清は\#8a リンパ節から郭清をはじめるが No.8p と連続している場合は総肝動脈背側部分を\#8p として扱う. No.12a は固有肝動脈を簬出させながら郭 清し門脈左縁が露出するまでを郭清範囲としている. No.11p 後胃動脈 (温存する) が脾動脈から離れて立ち 上がる部位までを目安に郭清する，左胃動脈の左右根部 を露出するようにNo.9を郭清し左胃動脈を切離する。 総肝動脈, 固有肝動脈, 脾動脈へのテーピングは行って いない. 以上の郭清を行うにあたり膵を損賃することな く正確な郭清を行うには出血させないことが重要であ る。我々は開腹手術において，ほとんどの操作を電気メ スで行っている，電気メスを使用する際は通常カウンタ ートラクションが重要であるが, 過度の牽引は小血管か らの出血の原因となる，郭清すべき組織を把持展開する 力を必要な最低限度に抑えること，助手の膵上縁を展開 する力の強弱を変えないことが重要である. (成績) 2003 . 5月から2004.4月に杍る幽門側胃切除でD 2 以上の郭 清を行った83例て睟液ろうは 1 例も認めていない。 
VS-9-5

圊癌に対する D 2 郭清の手技

福島県立医科大学第 1 外科"，岩手医大第 1 外科 ${ }^{2)}$

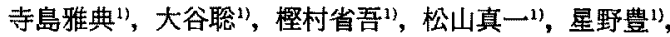
木暮道彦 ${ }^{1)}$, 後藤満一1), 阿部薫 ${ }^{2)}$, 高金明典 ${ }^{21}$, 斎藤和好 ${ }^{2}$

【目的】胃癌治療ガイドラインでは D 2 郭清が定型手術 とされているが，各リンパ節の郭清手技は設間で大きく 異なるものと思われる。今回, 我々の行っている胃癌 D 2 郭清手技のポイントを供覧する。【適応】D 2 郭清の適 応症例は基本的に胃癌治療ガイドラインに準拠している が, $\mathrm{sN} 2$ 症例は稳極的にD 3 部清を行っているため除 外した。手技】始めにsT 1 , sT 2 症例ては ICG の漿 膜下注入によるセンチネルリンパ節生検を行っている。 原則として大網は温存し, 明らかな $\mathrm{N}+$ 例を除いて迷走 神経肝枝，腹腔枝も温存している。幽門側胃切除 (DG) では大絧切離後左胃大網動脈を切離, その後右側の処理 に移り，No.14v から No.6を郭清し右胃大網動脈を切 離、更にNo.12a を郭清し右胃動脈を切離十二指得を 離断後 No.8a から No.9, No,11p 剠清し, 左胃動脈 を切離. 最後にNo.1，No.3を郭清し胃を切離している. 胃全摘（TG）で脺温存・脾摘を施行する際には脾動脈： 脾静脈共に脺尾部まで温存している. 尚, 郭清に際して はリソパ漏予防の目的でハーモニックスカルペルを多用 している、成續】DG，TGに扔ける手術時間，出血量は 198分士38分, $247 \pm 43$ 分, $256 \pm 133 \mathrm{~g}, 427 \pm 249 \mathrm{~g}$ であっ た. 平均郭清個数は DG て $40.6 \pm 12.2$ 個, TG

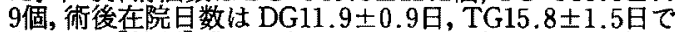
あった。【結語】我々の行っているD 2 郭清は手術時間, 出血量, 郭清個数, 在院日数などからみて定型手術とし て妥当な術式と思われた。

VS-9-6

胃癌取り扱い規約に準じた胃切先行の胃 癌 D 2 郭清, 槳膜浸潤例の手術

横浜市立大学医学部臓器病態治療医学 ${ }^{11}$, 横浜市立大学 医学部附属市民総合医療センター消化器病センター2)

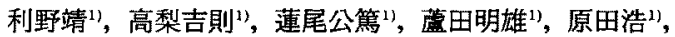
川本昌和"，和田博雄"，千葉明彦"1，荒井宏雅"1, 西井鉄平 ${ }^{11}$, 稻垣大輔 ${ }^{12}$, 羽鳥慎祐 ${ }^{21}$, 山田六平 ${ }^{21}$, 今田敏夫 ${ }^{2)}$

当科でうこなっている胃癌に対する幽門側胃切除術D2

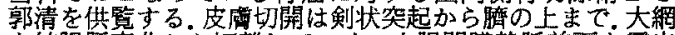
を結腸肝弯曲から切郁していく，上腸間膜静脈前面を露出 し右胃大網静脈根部への静脈と下膵十二指腸静脈を確㒛 $\mathrm{L}$, 右胃大網静脈根部を切離。膵葴前面の腹膜を涂離 $\mathrm{L}$, 右 胃大網動脈を根部で切離.十三指腸を切離. 右胃動脈根部て 切離，固有肝動脈の左側を胆管の高さまで部清小網を切

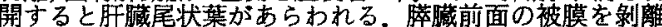
しつつ膵缄上緑で総肝動脈を露出していき, \#12a の部清し た脂肪織と連続させて，右横隔膜脚に連続するように腹膜 を切開，ここで胃の口側の切離線を決め，切離線上の大弯， 小弯の血管を処理. 胃を自動縫合器で切離。この操作でこれ 以後の解剖肪分がりやするる。大弯の血管㚭理を口側に 進め左胃大網動脈，静脈を根部で切離する操作も容易であ

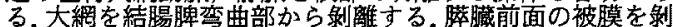
離を脺缄尾側に進め脾動眽周国を郭清, 横隔膜左脚の腹膜

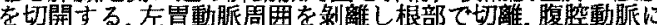
沿って横隔膜脚の間を郭清 胃小弯の口側の郭清を腹部食 道まで進め先の郭清に連䋨させる，膵臓前面の剶離した被 膜をガーゼで結腸間膜前を結腸側にこする事で别離し， 大網を結腸付著部て切離し胃切除術を終了する再建は曾 癌の漫潤が十二指腸近傍に及ぶ時は結腸後経路の RouxY，そうでなとをは Billroth-I 法再建としている。
VS-9-7 一般病院における胃癌D2 郭清の理解 と成續

坪井病院外科" , 今泉西病院外科 ${ }^{2)}$, 日本医科大学臟器病 態制御外科 ${ }^{3}$

山下直行 ${ }^{11}$, 湖山信篤 ${ }^{1)}$, 吉田初雄 ${ }^{2)}$, 櫻澤信行 ${ }^{11}$, 渡㟟睦弥"1，中山浩一"1)，日吉晴久 ${ }^{13}$ ，細野由紀子1)， 岩波洋 ${ }^{2}$, 左近司光明 ${ }^{1)}$, 田原孝 ${ }^{3)}$

当院では D 2 を標準として胃癌手術を行ってきた。【5 生率】 1984-1998年(1245例) StageIa (580) $99.1 \%$ ，Ib (170) $89.7 \%$, II (124) $73.9 \%$, IIIa (116) $65.0 \%$, IIIb (80) $44.5 \%$. IVa (48) $23.6 \%$, IVb (121) $0 \%$.(他病死打 与切 bj 【リンパ節転移] 1984-2003年 (1745例) L/LD(553例) $\# 1(2.5 \%), \# 2(0 \%), \# 3(13.7 \%), \# 4 \mathrm{sa}(0 \%), \# 4 \mathrm{sb}$ $(0 \%), \# 4 d(12.3 \%), \# 5(4.0 \%), \# 6(20.7 \%), \# 7(5$. $8 \%), \# 8 \mathrm{a}(5.8 \%), \# 9(2.4 \%), \# 10(0 \%), \# 11 \mathrm{p}(0$. $4 . \%), \# 12 \mathrm{a}(0.4 \%), \# 12 \mathrm{~b}(0 \%), \# 12 \mathrm{p}(0.2 \%), \#$ $13(0.2 \%), 14 v(0.2 \%) \mathrm{LM} / \mathrm{M} / \mathrm{ML}(730$ 例) $\# 1(3.7 \%)$. \#2 $(0.7 \%), \# 3(20.4 \%), \# 4 \mathrm{sa}(0.3 \%), \# 4 \mathrm{sb}(1.0 \%)$ \# $4 \mathrm{~d}(15.1 \%), \# 5(4.5 \%), \# 6(9.6 \%), \# 7(9.5 \%), \# 8 \mathrm{a}$ $(4.7 \%), \# 9(3.4 \%), \# 10(0.3 \%), \# 11 \mathrm{p}(1.1 \%), \# 12 \mathrm{a}$ $(0.8 \%), \# 12 \mathrm{~b}(0 \%), \# 12 \mathrm{p}(0 \%), \# 13(0.3 \%), 14 \mathrm{v}$ $(0.3 \%)$ 【はとめ】12版までデー夕を中心とした解析 加ら住12a,14vの転移頻度は不明てあるがＬ/LDでは\# 6転移が最も高く，確実な\#6のため\#14vを行う意義があ り.13版加ら2 群となった\#12aは門脈の左側壁, \#14v は SMV 前面が膵下緑まで簬出されるように郭清. $\mathrm{sN}$ (十)では12a でPV 左側の背側緑に入った切開を右横隔 膜脚までつなげるように\#8p も一部郭清.L/LDは\#8,U は\#11pの転移が多くＬGA，CA 超えて反対側には転 移しにくい.13版の群分類は，適正かつ合理的だが,若干 の修正の可能性あり，幽門側切除を中心に供覽する。

VS-9-8 下部(L)胃癌に対する標準手術一特に No12a，14v リンパ節郭清についてー

金沢大学大学院がん局所制御学

藤村隆, 高井優輝, 中村度史, 大場大, 宮下知治, 木南伸一，二宮致，北川裕久，伏田幸夫，谷卓， 西村元一，望原正都，清水康一，太田哲生，三輪晃一

第13版胃癌取扱い規約よ D，L領域胃癌ては No12a，14 vリンパ節が第 3 群から第 2 群に改訂された。当科の進 行胃癌( T 2 以上) の中で, D $2+\alpha$ 以上が行われた症例 630例の検討では, No12a 転移は36例 (5.7\%), No14v 転 移は24例 (3.8\%)に諗められ, L領域中心の胃癌に限ると それそれ 9.4\%，8.2\%であった L領域畏癌のCur B に おいて, No12a も No14v も転移陽性例と陰性例との閒 に予後に差がなかった（それぞれ $\mathrm{p}=0.79, \mathrm{p}=0.74)$ 従つて今後 No12a 14v リンパ節郭清は中 2 として標 準化されるべき考えられるが，当科で行っている郭清 手技を供覧する。亦ず 葉の剝離を胃結腸静脈幹(TGC)まで進めてお゙き,脺頭部 前面の組織を脺頭から外すように郭清する。この時, 副 右結腸静脈，前上脺十二指腸静眽などTGC に゙流入する 静脈を結势切離した後に，TGCを根部で処理する，上腸 間膜静脈 (SVC) 前面の部清を脺下縁まで行い, 膵頭部前 面の剥離をNo 6 の方へ進め, 右胃大網動脈を根部を゙結

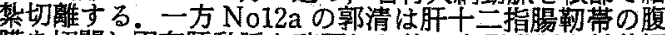
膜を切開し固有肝動脈を確認した後, 右霄動脈を結装切 離する。十二指腸を球部で切断し, 総肝動脈 (CHA)を脾 静脈が SVC と合流寸る部の前面で tapingする。固有胵 動脈前面の制離層を門脈左縁へとつなぎ No12p と共に郭清する。先に掛けた tapeを右外側下方 に牽引することにより，引き続き行われるNo 8 a,No 9 右の郭清が容易になる。 
D 2 リンパ節郭清

国立がんセンター東病院上腹部外科

木下平, 小西大, 中郡聡, 高橋進一郎, 後藤田直人

膵温存脾動脈周囲リンパ節郭清は，脾動脈を根部で切離 郭清する丸山の術式が普及した。しかし稀ではあるが温 存する膵体尾部の血流障害による難治性の膵液瘦を発症 する症例の経験から，根治性を落とさず血流を保持する ため, 脾動脈幹を根部から $5 \sim 6 \mathrm{~cm}$ 温存する方法で脺 液㾴の減少を目指してきた。開院以来この方法で郭清を 行った1992年から2002年までの273例の合併症による入 院死亡は 1 例 $(0.37 \%)$ のみであったが，minor なもの を含めた膵液瘦を中心とする脺関連合併症の発生率は 53/273（19.4\%）と低率とはなったもののまだ高く，満 足できるものではなかった．自動吻合器により繾合不全 が極めて少なくなった現在, 最も頻度の高い術後合併症 であり，入院期間延長の原因となっている。この問題を 解決するためには可及的に膵尾側まで脾動静脈を温存す る必要があると考え, 最近の症例では可能な限り脾動静 脈を温存した部清を行っている. 胃上部進行胃癌で脺に 直接浸潤がなく，脾動脈幹周囲リンパ節に肉眼的に明ら かな転移のない症例に適応し行っている。現在までに24 例に施行しているが脺関連合併症は minor な膵液瘦が 1 症例あったのみである。この点をポイントにして最近 われわれが行っているより安全な定型手術としてのD 2 リンバ節郭清をビデオで供覧する。

VS-10-1 小奣鼠径ヘルニアの術式の変僄一 40 年間 8839手術例の検討一

県立広島病院小児外科

古田靖彦，大津一弘，鬼武美幸

【目的】小児風径へルニアに対する手術術式はその発生 原因より simple herniorrhaphyに異論はなく多くの施 設で定着している。当科に於も過去40年間に時代と共に 術式の変遷を経てより簡単で安全な方法としてMitchell Banks 法（以下 MB 法）に至った。更に最近は傷 痕がほとんど残らないように皮切を㓌垔に置いた MB 変法 (Bianchi 法)を標準術式にしている。【方法と成績】 開設以来1964.5〜1976.5の12年間は Ferguson 法により 2600 例 (再発率0.03\%)，1976.6１991.8015年間は Lucas-Championniere 法 (以下 L-C 法) で3865例 (再発 率0.12\%)，1991.9〜2004.4013年間は MB 法で2357例 (再発率 $0.22 \%$ ). 手術所要時間(平均) は Ferguson 法: 男23.6分, 女16.4分, L-C 法：男20.8分, 女14.5分, MB 法：男10.5分, 女7.7分.【結論】小児鼠径へルニアの術 式は時代の変遷を経て MB 変法を標準術式にしている. 本法は合併症もほとんどなく，手術所要時間も短く，美 容的にも優れた方法と思われる。
VS-10-2 小児鼠径ヘルニアに対する腹腔鏡下閉鎖 術 (LPEC 法)

徳島大学病院小児外科 ${ }^{1)}$, 順天堂大学医学部小児外科 ${ }^{21}$ 嵩原裕夫"1)，石橋広樹 ${ }^{11}$ ，鳥羽昭三1)，宮谷智彦"1， 大下正晃 ${ }^{2)}$

【目的】小児鼠径ヘルニアに対する従来の鼠径管アプ ローチと異なり，腹腔鏡下に演者らの考案したラパヘル クロジャーを用いてへルニア門全周にタバコ縫合をかけ

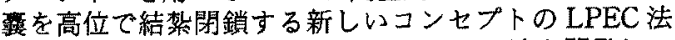
について報告する。【対象】1995年 LPEC 法を開発し， 1999年加らは当科の標準術式として2004年 4 月まてに 285例 (男児：170例，女児：115例，13生日～18歳）に対 し370件の LPEC 法を行った.【術式】臍部の $5 \mathrm{~mm}$ 創か ら外径 $4,5 \mathrm{~mm} の$ 腹整鏡を挿入。縫合系を把持した19Gage のラパヘルクロジャーで内瓦径輪の上縁を穿刺 し，臍部左側から刺入した16-Gageの鉗子で内鼠径輪周 用の腹膜を把持しながら，精管や血管を損傷しないよう に腹膜外でへルニア襄入口部全周に系をかけ結热する。

【結果】手術時間は両側で男児20分，女児15分である. 水瘤の術後発症はないが，吸収系を用いた 40 例中 4 例と

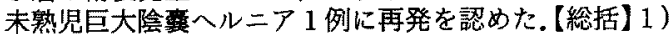
必要最少(小)の術創でヘニア桽を完全に閉鎖できる。

2) 精管や血管への損傷のリスクが極めて低い.3) 人 ルニア形態の鑑別が容易にできる，などの利点に加え， 従来の術式よりも simpleで cosmetic な面でも僈れて いる.

VS-10-3 小児鼠径ヘルニアに対する鏡視下手術 埼玉医科大学小児外科

谷水長丸，檜顕成，里見昭，高橋茂樹，村井秀昭， 米川浩伸，高橋浩司，酒井正人，池田理惠

【目的】1997年より現在までに小児鼠径ヘルニアに対し， 380例の鏡視下手術を経験した。教室の術式 Deschamps Needle 法(以下 DN 法)について報告する，【対象及び手 術適応】380例の内訳；年齢は生後27日-14歳（平均: 3 . 24墄), 男:女 $=175: 205$. 生後 3 ヶ月以後を手術適応と し，嵌頓歴を認める症例はその限りとしなかった。精系 水腫は 2 歳以上を適応とし, 停留精巣は全例適応とした。 なお PPVの手術適応は長さ $10 \mathrm{~mm}$ 以上とした.【術式】 臍輪下縁内側に $5 \mathrm{~mm}$ の皮店切開より 5 mmOptiview trocar を鏡視下に刺入. PPV の有無を確認. PPV を認 める症例ではスコープを内ソケイ輪部から $\operatorname{sac} の$ 底部ま で進め, PPV 長を測定. PPV 長 $10 \mathrm{~mm}$ 以上なら, 内鼠径 輪直上, 下腹壁動脈外側に $2 \mathrm{~mm}$ の皮切をおく. 同部よ りミニポートを穿刺し内鼠径輪周囲で sacの側壁から後 壁に trocar を淮め生食を注入，sac 全周を剝離する。 二ポート抜去後 Deschamps Needle を挿入し，その繁曲 内に sac を取り込み，創外へ引き出す，以後の手順は conventional 手術に準ずる.【まとめ】DN 法はsacを切 除する為, 術後精系水腫が発生する可能性はない, 再発 を 1 例認めたが，合併症は経験していない，創痕は目立 たず，整容的に満足のいくものであった，fmfy 
VS-10-4 再発·術後疼痛予防に必要な確実な Plug 固定のポイント

（医）涼友会執行クリニック・神楽坂 D.S.マイイクリニッ ク

執行友成，小島伸，松橋亘，永田傅

M-P 法による，再発・術後疼痛の予防は確実な Plug 固 定にある。【目的】日㷌り・1泊入院による早期復㷌老可 能にした M-P 法では後壁破燷・E大ヘルニア雚・顿頓型 はそけい輪の閉鎖が出来ないと考えられているが, 確実 な Plug 固定を行う事により再発率の低下 $7 / 1500=$ 0. 4\%, 術後神経痛無く経過している。術式のポイント

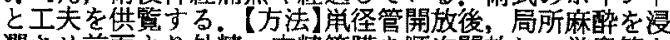
潤させ前面より外精 - 内精筋膜を順次開放し，举悬筋も 前面より剥離切断する事によりヘルニア臷と精巢動静 脈・精索を後壁より剶離し横筋筋膜を完全に露出子る。 内腹斜筇を単径輪が直視できるまで開放する。単徍輪を

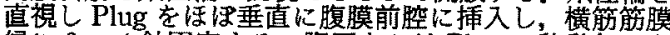
緣に $3 \sim 4$ 針固定する. 腹圧を加けPlug の移動無きを 確認後 on lay sheet を恥骨前面骨膜に 1 針, 内側横筋筋 膜, 外側単径鞄带に各縫合. 頭側を内腹斜筋の後面八㨉 入する。【成續了98年より2004年5月まてに約 $7 / 1500=$ 0. $4 \%$ の再発率てある.従来法は単径管内を後壁より一

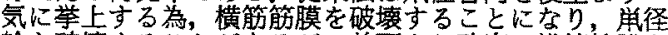
輪も破埣方ることがあるが，前面より確実に横筋朌膜を 露出することにより確実な Plug 固定が可能となり,再 発・術後神経痛を予防できる、【結論】確実な横筋筋膜の 露出を行い，単佳輪を直視することがPlug 固定では大 事であり，on lay sheet を内腹斜筋の後面八㨉入する事 により確実な後壁補強が完成する。

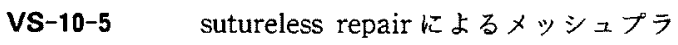
グ法の多施設研究

市立四日市病院外科 ${ }^{12}$, 名古屋大学第二外科 ${ }^{2}$

長井俊志 ${ }^{1)}$, 蜂須賀丈博 ${ }^{21}$, 中尾昭公 ${ }^{21}$, 村井俊文 ${ }^{1}$, 村田巨樹 ${ }^{1}$, 岩瀬勇人 ${ }^{13}$, 渡辺卓哉1), 久野泰1), 森敏宏 ${ }^{13}$, 篗原正彦1，宮内正之 ${ }^{11}$

はじめに)メッシュプラグ法は，1989年 Rutkowにより 開発され1995年より我が国人挐入された。われわれは， この方法をいち早く採用し，現在までに1300例以上の症 例を経験した。今回, 名古屋大学第二外科関連病院18施 設で, 直接へルニアに対するメッシュプラグ法において onlay patchの固定が必要であるか否かを中心に, prospective study を行ったので, 手技をビデオで供覧する とともに，結果を竍告する．手技）直接へルニアと診断 した場合，横筋筋膜の全周性剝離を完全に行う、断端を ペアン錳子で把持した後, 主にEL のプラグを選択括入 する。立た，腹膜前筋膜も可能な限り全例確認し，㢦離 する．横筋筋膜と吸収系で数針固定するが，不安定な場 合には恥骨と IP tractに固定する. Onlay patchは，恥 骨を覆うように挿入し原則固定はしない. 結果) 142 症例 を登録し，一年後に全例アンケート調査を行った。回収 105例(回収率 $86 \%$ )。プラグ固定は平均5，6針，patch 非 固定100例, 固定41例. 再発を 3 例に認めた。 1 例は patch 非固定， 2 例は固定例であった. 結論）メッシュプラグ 法に㧍ける再発は, patch の固定の有無ではなく,プラグ の固定不良に起因する可能性が高いと考えられる。
VS-10-6 成人鼠径ヘルニアに対する局所麻酔下 PHS 法 Day Surgery

大阪市立大学腫瘍外科

金原功，澤田鉄二，山下好人，高畑哲也，井上透， 西原承浩，八代正和，前田清，西口幸雄，加藤保之， 平川弘聖

近年, Day Surgery の適応が広がりつつあるが, 安全 に手術を行うには，十分なIC と麻眙法扔よび手技の工 夫が必要である。当科では平成11年よりPHSを用いた 局所麻醉下 Day Surgeryをこれまて168件施行してきた ので,その手技の䒠際，成績について紹介する。1\%塩 酸りドカインにて皮下, 皮内, 深部脂肪織の順に局所麻 醉を行い, $5 \mathrm{~cm}$ の皮措横切開を加える.後の深部での疼 痛を助長しないよう, 外腹斜筋腱膜に到達するまでは慎 重に操作を進め，皮下以降，電気メスは使用せず血管は 結热し，てきるだけ鋭的切離を行う。この時点で腱膜下 に局麻を精索全体に広がるよう十分に浸潤麻酔を行引 が,この麻醉により以後ほとんど麻酔は必要としないこ

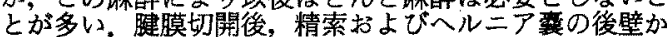

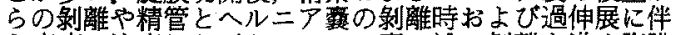

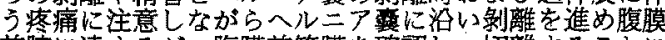
前腔に達卞るが，腹膜前筋膜を確認し，切灕军ることに より腹膜前腔の正しい層に入れは用手的剥離にてほとん ど痛みなく剥離可能である。以後は常法に従いPHSを 挿入しへルニア修復術を完了，創は皮下埋没縫合後，ダ 一マボンド使用したここれまで168例全例に局所麻醉のみ で手術可能で，4例に軽度の徐脈，血圧低下を認めた以 外，術中合併症なく，りドカイン使用量は15.8 ml (13-20 $\mathrm{ml})$, 手術時間は平均 72 分で, 術直後より歩行可能であっ た。術後 3 例に Seroma を認めた以外, 術後合併症, 再 発は認めていない。

VS-10-7 成人鼠径へルニアに対するKugel 法の 選択と手技上の留意点 佳田厚生会佐田病院外科

小田斉, 中村光成, 植木敏幸, 佐田正之

Kugel 法は形状記憶 inlay patch を用いた直視下の腹膜 前新アプローチで当院では2003年より成人鼠径ヘルニア に対する第一選択とし初発135例，再発10例(前手術：还 来法 3 例, TAPP 法 4 例, Lichtenstein 法 2 例, MP 法 1 例)，間接型96例，直接型38例，パンタロン型8 例, 犬 腿ヘルニア3例に同法を施行した。嵌頓合併6例中5例 は腹膜を切開し腹空側より僄納できなが1例は前方アナ゚ ローチに変更した。手衍時間は初発例 $32.5 \pm 14.1$ 分, 再 発例 $55.0 \pm 25.9$ 分。入院期間 $2.8 \pm 3.2$ 日 した。合併症注膀脂損傷 1 例でMP 後再々発症例の恥骨 傍に突出したplug 剔離中に発生した。再発は導入初 期 1 例と TAPP後再登泟例 1 例で腹膜前腔の不等分な 㔀離が原因だった. Kugel 法は再発例や嵌頓例にも有効

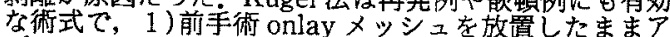
プローチできる；2）必要に応じて腹膜を切開し腹空内 加発生形式や解剖を確認できる；3)腹腔鏡下手術に 比へ手技が容易である;などの利点がある、しかし腹膜

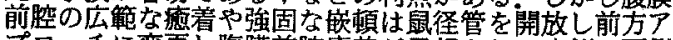

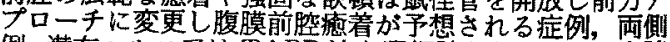
例, 潜在へルニアはTAPP法も選択肢としている.当院 での過去12年間の成人鼠径ヘルニア1083例に対する術式 は従来法155例, TAPP 法250例, TEPP法51例, MP 法 230例, PHS 法252例, Kugel 法145例であった。術式の爱 遷と各術式の手術成續を示し再発例や嵌頓例に対寸る Kugel 法の手技上の留意点をビテオで供覧する。 